\title{
A Pragmatic Study of Speech Acts Pertaining to Health Advice in Covid-19 Pandemic
}

\author{
Bareq Raad Raheem (Ph.D. Research Scholar) \\ Raashid Nehal (Professor) \\ Department of English, Aligarh Muslim University, Aligarh, 202002, UP, India
}

Received: October 16, 2021 Accepted: November 1, 2021 Published: November 2, 2021

doi:10.5296/jsel.v9i1.19137ＵRL: https://doi.org/10.5296/jsel.v9i1.19137

\begin{abstract}
People use the language to make propositional statements, entities, objects, state of affairs, and so on and fulfil functions such as apologising, introducing, requesting and denying, etc. Speech act can be described as the action performed in uttering something, and the directives are functions to direct people's behaviour. Advice is a directive speech act. Different linguists classified the advice into direct, indirect, and conventionally indirect. The use of advice has been applied in communication and the written form of humankind for a long time. The speaker intended to give benefit to the hearer when he /she gives advice. The present study intended to shed light on the notion of the pragmatics of communication of health advice in covid -19 . The data of this study were fifteen public health advice related to covid-19 collected from the official website of the World Health Organisation (WHO). They have been analysed pragmatically based on their type, strategies, and advisories. The study also aims to find out the consciousness of EFL learners with the health advice of covid-19 and what degree of conciseness comes and literal comprehension. The results of the pragmatic analysis have shown that the frequent type of advice is directive, the frequent strategy is imperative, and the frequent advisories is advising. At the same time, the results of the conducted interview have shown full consciousness, partial consciousness, and non-consciousness of the health advice of covid-19.
\end{abstract}

Keywords: Pragmatics, Speech act, Directive speech act, Advice, Covid-19 


\section{Introduction}

People use language for communicating with each other to fulfil their needs by exchanging thoughts and ideas. Therefore, being able to communicate effectively considers an important skill. Yule (2010) refers to the significance of what the speaker means by his/her utterance. That means the speaker tries to convey meaning to the hearer, whereas the hearer tries to understand what the speaker means by saying a statement in a particular context. Consequently, the deep understanding of how language is used is significant for both speaker and hearer to make the communication run well.

\section{What is Pragmatics?}

Pragmatics is the scientific study that deals with the meaning which cannot be inferred by semantic theory alone. It is a systematic method of comprehending the meaning of the language used in a context. For example, when someone utters a sentence, the speaker is trying to bring change in the behaviour of the listener. Morris (1938) describes pragmatics as how interpretations and signs correlate with each other. Yule (1996) indicated that pragmatics points out the meaning of contextual expressions and the connection between the form and speaker using that form. In line with the definition of Yule, Crystal in Barron (2003) defined pragmatics as the study of the language from the point of view of the users, especially the decisions they decide, restrictions they face in utilising the language in social interaction. Mey (1993) says that pragmatics is studying the conditions of human language usage that is determined by context. Levinson (1983) stated a statement similar to Mey's one. He described pragmatics as a study of language use, which means studying the relation between the language and context that considers as basic to understand the language. Finch (2000) pragmatics emphasises what is not explicitly specified and how can understand utterances in the sense of circumstances. Pragmatics is studying how people utilise the language for communication purposes. It dealt with utterance meaning in a particular context by the speaker and interpreted by the hearer.

\section{The Scope of Pragmatics}

How people use the language for communication is studied through pragmatics. It is one of the scopes of linguistics that studies the meaning. For example, speech act theory deals with the meaning of an act performed in the speaker's utterance in a particular context.

Advice is a directive speech act which been used by humankind. It is intended to give benefit to the hearer. Nowadays, the whole world is fighting the invisible enemy, the covid-19. The outbreak of covid-19 has been impacting all aspects of human life Raheem et al. (2020). Different strategies and rules have been followed since the emergence of this virus, such as lockdown, vaccinations, health advice, etc. World health organisation (WHO) has been giving health advice to the public to reduce the spread of this virus. In addition, it has been warning the people of the dangers of this virus and its impact on human life.

At the time of covid-19, everyone can notice the advice of covid-19 whether in Tv channels, posters, advisement screens, and other means. The present study will be dealing with health advice of the covid-19 pandemic in the official site of WHO. 


\section{Speech Act Theory}

John Austin (1962) is a linguist and philosopher who proposed the Speech Act theory in his book, How to do Things with Words, published after his death. This work was later taken up by one of his students, John Searle (1969). Austin explains speech acts as the actions performed in uttering something. He indicates that speaking a language means performing speech acts to make promises, ask questions, give commands, say statements, etc. Yule (1996) gives an almost identical definition; he says that speech acts as actions performed in saying something. On the other hand, Searle (1969) indicates that the sentence's production under certain conditions is a speech act, and it is a minimal unit or the basis of linguistic communication. Thus, viewing speech acts as the basic unit of communication allows Searle to explicitly associate speech act with the study of language (its production and interpretation) and meaning (speaker meaning and linguistic meaning).

\section{Directive Speech Acts}

Austin (1962) defines the different categories of Speech Acts as locutionary act, perlocutionary act, and illocutionary act. Meanwhile, Searle (1969) states that the speaker's utterance can perform three different acts: prepositional acts, utterance acts, and illocutionary acts. This study deals with directive speech act as subfield or part of illocutionary acts according to the classification of Searle (1979). According to Searle (1979), directives are the speaker's attempts to get the hearer to do something as advising, recommending, requesting, ordering and commanding, etc. They explain what the speaker wants. In this regard, Yule (1996) states that the speaker attempts to make the world fit the word by using the directive. He described directive speech as a kind of speech act that the speakers use to get someone else to do something. He also explained that directive speech acts represent the effort on the speaker's part to get the hearer to do something. These are based on the illocutionary point. Despite the varied syntactic structures, directives are perceived in several ways through the interaction based on the degree of politeness. The following sentences are an example of the directive:

1. Freeze

2. You may ask

3. Would you make me a cup of coffee?

The first sentence is an example of the command; the speaker is commanding someone to freeze something. The second sentence is an example of suggestion, and the speaker wants the hearer to do something as he /she suggests. Finally, the third example is an interrogative sentence, and the speaker performs a request with a function to get the hearer to do something that the speaker wants. Here, the speaker doesn't want to respond by yes or no but the act of making a cup of coffee for him/her.

\subsection{The Concept of Advice Under the Category of Directive Speech Act}

According to Searle (1969), giving advice is a kind of speech act the speaker believes will be benefitable to the hearer. He refers that the speaker is doing the hearer a favour by advising because it will be unclear for both of them that the hearer will do the act without the advice 
being given. In this regard, Brown and Levinson (1987) said that advice tells what is best for someone. They mentioned that advice belongs to the directive speech act. They also referred that advice is related to the group of advisories as part of speech that includes recommendations and suggestions as well.

Hinkel (1997) describes giving advice as a complex speech act that should be performed with caution when the speaker is sensibly certain that the hearer is expected to do what is being advised. It's important to make all sorts of advice soften and never given explicitly to avoid offending the hearer, and the speaker should have the right to give advice.

At the same time, DeCapua and Huber (1995) indicated that there is a variance between unsolicited and solicited advice. They also point out that there is a difference between the advice given in public or expert settings versus private settings between friends.

Linguistically, Leech (2014) describes the imperative as the most direct form of advice, such as: you look not feeling well, Go to the doctor. However, according to Martinez-flor (2003), there are three types of strategies that have been used to imply the speech act of advice:

1. Direct which can be four realisations:

a. Imperative such as washing your hands

b. Negative imperative as in: don't rub your eyes.

c. Declarative in modals (ought to and should) such as : you should help him

d. Declarative by using performative verbs as: I advise you to be more aware.

e. Declarative with noun advice as in: my advice to you to help them.

2. The indirect conventionalised strategy includes conditional as in: buy a new shirt if you go to the mall.

3. Indirect non-conventionalised strategy in which advising is produced by a hint: you want to go to a swimming pool, don't you?

The present study is concerned with the public advice given by WHO amid the covid-19 pandemic. Because of the pandemic, Advice Speech Acts were boomingly in use. Therefore, this merits more attention for research.

\section{Felicity Conditions}

In speech act theory, the felicity conditions must be fulfilled for a speech act to be satisfactorily realised or performed. These conditions are related to conversational and situational context, the speaker's beliefs and abilities, and the hearer. Moreover, Searle (1969) indicated that felicity conditions of an utterance are constitutive rules because they are not something that can go for right or wrong or be abused but something which can make up and define the act itself. This part will give a brief discussion to the felicity conditions of the advice speech act and the felicity conditions of health advice:

\subsection{Felicity Conditions of Advice}

Basically, Searle (1969) classified the felicity conditions of the speech act of advice into four conditions as: Prepositional condition. Preparatory condition, sincerity condition, and essential condition. The prepositional condition means that the speaker guesses or imagines 
the future act of the hearer. In the preparatory condition, the speaker believes that the act will give a benefit to the hearer. The third condition is the sincerity condition, and here the speaker is definitely sure that the action will benefit the hearer. Lastly, in the essential condition, the speaker knows that the hearer will not be interesting in following his/her advice.

\subsection{Felicity Condition of Health Advice}

The felicity conditions of health advice have been indicated by Van Poppel (2013). He classified the felicity conditions of health into four conditions as: essential condition, prepositional condition, preparatory condition, responsibility condition. These conditions have been considered by WHO while directing people to follow their advice, but this paper's concern is only the pragmatic understanding by the respondents.

The essential condition is the condition in which the advisor attempts to make the hearer performs an act that can benefit him/her in avoiding or treating a problem that might affect the hearer's health.

Prepositional condition refers to a condition in which the advisor imagines or expects a future act that may benefit the hearer. The preparatory condition represents the condition in which the advisor believes that his / her advice will be benefitable to the hearer's health by avoiding and treating a health issue. Here the advisor beliefs that the hearer will be willing and able to perform the action. Finally, the responsibility condition is the fourth condition in which the speaker wants the hearer to act an action that will benefit the hearer's health.

\section{Research Methodology}

\subsection{Data Collection}

The present study is concerned with the advice as a directive speech act in the public health advice of the covid-19 pandemic. The data of this study are fifteen public health advice that has been selected from the official site of the world health organisation (WHO) to be analysed pragmatically. Moreover, an interview has been conducted with ten EFL learners at Aligarh Muslim University. The idea is to find out the consciousness with the health advice of covid-19 and what degree of consciousness comes and literal comprehension.

\subsection{Subject of the Study}

A toal number of ten male postgraduate students (PG) were the subject of the present study. They were all native speakers of Arabic. They enrolled in master's studies in different departments in Aligarh Muslim University. Due to the lockdown rules, the researcher has interviewed them by visiting them at their residences and hostels. All the subjects have shown a good knowledge and proficiency in the English language.

\subsection{Data Analysis}

This section is devoted to analyses of the collected data. The data has been analysed pragmatically and based on the subjects' conciseness and the literal comprehension of health advice of covid-19. Two tables have been designed to explain each of the mentioned analyses. 
Since the felicity conditions are considered by the person (in this case WHO) who is advising, therefore, this has not been considered in the analysis as it would require a separate study to be undertaken. Thus, undivided attention has been given to the analysis of the comprehension of the advices given by WHO by the respondents participating in the study.

The first table contains four columns has designed to show the pragmatic analyses such as structure, type of advice, strategies, and advisories, as shown in Table 1.

Table 1. The pragmatic analysis of the health advice of covid-19

\begin{tabular}{|c|c|c|c|c|}
\hline No & Structure & Type of advice & Strategies & Advisories \\
\hline 1. & Wear a mask & Direct & Imperative & Advise \\
\hline 2. & Wash your hands & Direct & Imperative & Advise \\
\hline 3. & Sanitise your hands & Direct & Imperative & Advise \\
\hline 4. & $\begin{array}{l}\text { Maintain at least one-meter } \\
\text { distance between yourself } \\
\text { and others }\end{array}$ & Direct & Imperative & Advise \\
\hline 5. & $\begin{array}{l}\text { Don't touch your eyes and } \\
\text { nose }\end{array}$ & Direct & $\begin{array}{l}\text { Negative } \\
\text { imperative }\end{array}$ & Advise \\
\hline 6. & $\begin{array}{l}\text { Avoid crowded or indoor } \\
\text { settings }\end{array}$ & Direct & Imperative & Recommend \\
\hline 7. & $\begin{array}{l}\text { Avoid touching your eyes, } \\
\text { nose, and mouth }\end{array}$ & Direct & Imperative & Recommend \\
\hline 8. & $\begin{array}{l}\text { Clean and disinfect surfaces } \\
\text { frequently, especially those } \\
\text { which are regularly touched }\end{array}$ & Direct & Declarative & Advise \\
\hline 9. & $\begin{array}{l}\text { Stay home and self-isolate } \\
\text { even if you have minor } \\
\text { symptoms such as cough, } \\
\text { headache, and mild fever }\end{array}$ & $\begin{array}{c}\text { Indirect } \\
\text { conventional }\end{array}$ & Conditional & Recommend \\
\hline 10. & Don't use masks with valves & Direct & $\begin{array}{l}\text { Negative } \\
\text { imperative }\end{array}$ & Advise \\
\hline
\end{tabular}




\begin{tabular}{|c|c|c|c|c|}
\hline 11. & Clean hands frequently & Direct & Imperative & Advise \\
\hline 12. & $\begin{array}{c}\text { Cough or sneeze into bent } \\
\text { elbow or tissue }\end{array}$ & Direct & Imperative & Suggest \\
\hline 13. & $\begin{array}{c}\text { When you take off a mask, } \\
\text { store it in a clean plastic bag, } \\
\text { and every day either wash it } \\
\text { if it's a fabric mask or } \\
\text { dispose of a medical mask in } \\
\text { a trash bin }\end{array}$ & $\begin{array}{c}\text { Indirect } \\
\text { conventional }\end{array}$ & Imperative & Recommend \\
\hline 14. & Open windows & Direct & Imperative & Advise \\
\hline 15. & Stay home & & & Direct \\
\hline
\end{tabular}

Based on the pragmatic analyses in table no.1, it has shown that the frequent type of health advice of covid-19 was directive. Moreover, the imperative was used frequently as a strategy for most of the advice. Likewise, the advice was used frequently as an advisory. A more or less similar result has been shown in studies conducted by Abass, a. H et al. (2020) and Al-Azzawi, Q. O et al. (2021).

The second table shows an analysis based on what the subjects understand and the implied meaning of health advice of covid-19.

Table 2. The consciousness of EFL subjects of health advice of covid-19

\begin{tabular}{|c|c|c|c|}
\hline No & $\begin{array}{c}\text { What do the health } \\
\text { experts say? }\end{array}$ & $\begin{array}{c}\text { What do the subjects } \\
\text { understand? }\end{array}$ & $\begin{array}{c}\text { What is the implied } \\
\text { meaning? }\end{array}$ \\
\hline 1. & Wear a mask & Use mask (7) & $\begin{array}{c}\text { To protect my- self from } \\
\text { infection (7) } \\
\text { Safety (2) }\end{array}$ \\
\hline 2. & Wash your hands & Clean my hands (9) & Maybe im infected (1) \\
\hline & Protect yourself (1) & $\begin{array}{c}\text { Cleanness (6) } \\
\text { To save myself (3) } \\
\text { To reduce the germs in } \\
\text { hands(1) }\end{array}$ \\
\hline
\end{tabular}




\begin{tabular}{|c|c|c|c|}
\hline 3. & Sanitise your hands & $\begin{array}{c}\text { Use sanitiser (8) } \\
\text { To kill the germs (1) } \\
\text { To keep my hand clean(1) }\end{array}$ & $\begin{array}{l}\text { Kill the germs (5) } \\
\text { Kill the virus (2) } \\
\text { Keep my hands clean(1) } \\
\text { To protect myself from } \\
\text { infection(1) }\end{array}$ \\
\hline 4. & $\begin{array}{l}\text { Maintain at least a } \\
\text { 1-metre distance } \\
\text { between yourself } \\
\text { and others }\end{array}$ & $\begin{array}{c}\text { Social distance (6) } \\
\text { Be away from crowded places } \\
\text { (1) } \\
\text { To keep myself safe (2) }\end{array}$ & $\begin{array}{c}\text { Social distance (6) } \\
\text { Safe my self and family } \\
\text { (2) } \\
\text { To avoid spreading the } \\
\text { infection(1) }\end{array}$ \\
\hline 5. & $\begin{array}{l}\text { Don't touch your } \\
\text { eyes and noise }\end{array}$ & $\begin{array}{l}\text { Don't touch your face (6) } \\
\text { Protect yourself from } \\
\text { infection(1) } \\
\text { Don't touch your eyes and } \\
\text { noise }(1)\end{array}$ & $\begin{array}{l}\text { To avoid the infection( } 6) \\
\text { Noise and eyes help the } \\
\text { virus goes inside the } \\
\text { body(2) }\end{array}$ \\
\hline 6. & $\begin{array}{l}\text { Avoid crowded or } \\
\text { indoor settings }\end{array}$ & $\begin{array}{c}\text { To Avoid crowded places(9) } \\
\text { To protect yourself from } \\
\text { covid-19(1) }\end{array}$ & $\begin{array}{l}\text { Don't go to crowded places } \\
\qquad(5) \\
\text { To keep myself safe(3) } \\
\text { Crowded places are not } \\
\text { safe(2) }\end{array}$ \\
\hline 7. & $\begin{array}{l}\text { Avoid touching your } \\
\text { eyes, nose and } \\
\text { mouth }\end{array}$ & $\begin{array}{l}\text { To protect myself (4) } \\
\text { Don't touch my face (3) } \\
\text { To avoid the infection (1) }\end{array}$ & $\begin{array}{l}\text { To avoid virus entering my } \\
\text { body } \\
\text { Avoid (5) } \\
\text { Keep myself safe(2) }\end{array}$ \\
\hline 8. & $\begin{array}{l}\text { Clean and disinfect } \\
\text { surfaces frequently, } \\
\text { especially those } \\
\text { which are regularly } \\
\text { touched }\end{array}$ & $\begin{array}{l}\text { To keep the surfaces clean (5) } \\
\text { To Clean the house properly } \\
\text { (1) } \\
\text { To Kill the germs(3) }\end{array}$ & $\begin{array}{l}\text { To protect myself (4) } \\
\text { To kill the germs(3) }\end{array}$ \\
\hline 9. & $\begin{array}{l}\text { Stay home and } \\
\text { self-isolate even if }\end{array}$ & I have to stay home (7) & Maybe im infected (5) \\
\hline
\end{tabular}




\begin{tabular}{|c|c|c|c|}
\hline & $\begin{array}{l}\text { you have minor } \\
\text { symptoms such as } \\
\text { cough, headache, } \\
\text { mild fever }\end{array}$ & Home -isolation (3) & $\begin{array}{l}\text { For our and public safety } \\
\qquad(2) \\
\text { To not spread the } \\
\text { infection(1) }\end{array}$ \\
\hline 10. & $\begin{array}{c}\text { Don't use masks with } \\
\text { valves }\end{array}$ & $\begin{array}{c}\text { Don't use a mask that contains } \\
\text { a valve }(5)\end{array}$ & $\begin{array}{l}\text { It's no safe mask } \\
\text { (3) } \\
\text { This mask cant protect } \\
\text { you(2) }\end{array}$ \\
\hline 11. & $\begin{array}{l}\text { Clean hands } \\
\text { frequently }\end{array}$ & $\begin{array}{c}\text { To keep my hands clean (8) } \\
\text { Wash my hands ( } 2)\end{array}$ & $\begin{array}{l}\text { Cleanness (6) } \\
\text { To kill the germs (4) }\end{array}$ \\
\hline 12. & $\begin{array}{l}\text { Cough or sneeze into } \\
\text { bent elbow or tissue }\end{array}$ & $\begin{array}{l}\text { To use tissue while sneezing or } \\
\text { coughing (4) } \\
\text { To not spread the virus (4) }\end{array}$ & $\begin{array}{l}\text { To keep the other safe (5) } \\
\text { To not spread the virus (2) }\end{array}$ \\
\hline 13. & $\begin{array}{l}\text { When you take off a } \\
\text { mask, store it in a } \\
\text { clean plastic bag, } \\
\text { and every day either } \\
\text { wash it if it's a fabric } \\
\text { mask or dispose of a } \\
\text { medical mask in a } \\
\text { trash bin }\end{array}$ & $\begin{array}{l}\text { To through my mask in the } \\
\text { trash bin (2) } \\
\text { To through my mask in the } \\
\text { proper place(4) } \\
\text { Don't through your mask in } \\
\text { public places or randomly }\end{array}$ & $\begin{array}{c}\text { Mask is means of } \\
\text { spreading the virus (5) } \\
\text { To keep the others safe (2) } \\
\text { Maybe the mask carries } \\
\text { the virus( } 2)\end{array}$ \\
\hline 14. & Open windows & $\begin{array}{c}\text { To get fresh air (5) } \\
\text { Ventilation (3) } \\
\text { To Change the air of room (2) }\end{array}$ & $\begin{array}{c}\text { Fresh air } \\
\qquad(6) \\
\text { Change the air of the room } \\
\text { (1) }\end{array}$ \\
\hline 15. & Stay home & $\begin{array}{c}\text { To stay home }(8) \\
\text { To keep yourself safe }(2)\end{array}$ & $\begin{array}{l}\text { To keep myself safe ( } 7) \\
\text { To keep myself and my } \\
\text { family safe ( } 3 \text { ) }\end{array}$ \\
\hline
\end{tabular}

Note: The number between the brackets in table No.2 refers to the number of subjects out of ten.

The table above has drawn out the subject's performance in an interview conducted with ten 
EFL learners in Aligarh Muslim University. The results have shown the disparity of the subject consciousness about the health advice of covid-19. The searcher has classified the results into three categories: full consciousness, partial consciousness, and non-consciousness. The full consciousness indicates the results of some subjects who have the consciousness to understand the health advice of covid and their implied meanings, such as in advice number 1,2 and 15. On the other hand, partial consciousness refers to the results that have shown a hindrance faced by some of the subjects in understanding the advice and its implied meaning, such as advice numbers 4,5,7.8,10 and 12. The non-consciousness indicates the subjects who can understand the advice, but they don't know their implied meaning, such as in advice numbers $7,8,9,12,13$, and 14 .

\section{Conclusion}

Pragmatics is one of the scopes of linguistics that can be considered as a systematic method of explaining language use in context. Speech act as a branch of pragmatics can be described as actions performed in saying something. Production of the sentence has taken under certain conditions is a speech act, and it is a minimal unit or the basis of linguistic communication. The advice is a directive speech act applied in communication and the written form of humankind for a long time. It is one of the notions which reflects an excellent picture to anyone who gives the advice to let the hearer gets a benefit. The use of health advice has gone viral amid the covid-19 pandemic. The health advice intended to provide instructions and warn the people of the coronavirus. The present study has shown that the frequent type of the health device of covid-19 was direct, whereas the frequent type of strategies was imperative. Using the direct strategy in most of the health advice is an indication of the seriousness and concern in providing advice speech act. The study has shown a disparity in understanding the health advice of covid-19 and their implied meaning, as shown in Table 2. It has shown that some subjects have the consciousness to understand the health advice of covid-19 and their implied meanings. This study has also shown a hindrance some subjects face in understanding the advice and its implied meaning. Moreover, it has shown that the subjects can understand the advice, but they don't know their implied meaning.

\section{References}

Abass, a. H., \& jameel, a. K. F. A. (2020). Pragmatic study of speech act of advice in selected English and Arabic children" s stories. https://doi.org/10.37648/ijrssh.v10i03.025

Al-Azzawi, Q. O., \& Majeed, S. (2021). A Pragmatic Study of Advising on Covid-19. Linguistica antverpiensia, 01-10.

DeCapua, A., \& Huber, L. (1995). 'If I were you...': Advice in American English. https://doi.org/10.1515/mult.1995.14.2.117

Finch, G. (2000). Linguistic terms and concepts. London: Macmillan Press Ltd.

Flor, A. M. (2003). Non-native speakers' production of advice acts: The effects of proficiency. Revista española de lingüística aplicada, (16), 139-153. 
Leech, G. N. (2014). The pragmatics of politeness. Oxford University Press, USA.

Levinson, S. (1987). Pragmatics. Cambridge: Cambridge University Press. https://doi.org/10.1017/S0022226700011324

Martínez Flor, A. (2005). A theoretical review of the speech act of suggesting: Towards a taxonomy for its use in FLT. Revista alicantina de estudios ingleses, No. 18 (Nov. 2005); pp. 167-187. http://hdl.handle.net/10045/5216

Morris, C. W. (1938). Foundations of the Theory of Signs. In International encyclopaedia of unified science (pp. 1-59). Chicago University Press.

Raheem, B. R., \& Khan, M. A. (2020). The role of e-Learning in COVID-19 crisis. International Journal of Creative Research Thoughts, 8(3), 3135-3138.

Searle, J. R. (1976). A classification of illocutionary acts. Language in society, 1-23. https://doi.org/10.1017/S0047404500006837

Tusi, A. (1994). English conversation. Oxford: Oxford University Press.

Yule, G. (1996). Pragmatics. Oxford: Oxford University Press.

Yule, G. (2020). The study of language. Cambridge university press.

\section{Copyright Disclaimer}

Copyright for this article is retained by the author(s), with first publication rights granted to the journal.

This is an open-access article distributed under the terms and conditions of the Creative Commons Attribution license (http://creativecommons.org/licenses/by/4.0/). 